\title{
Economic Competitiveness of Napier Grass in Irrigated and Non-irrigated Georgia Coastal Plain Cropping Systems
}

\author{
Marshall C. Lamb ${ }^{1}$ - William F. Anderson ${ }^{2} \cdot$ Timothy C. Strickland $^{3} \cdot$ Alisa W. Coffin $^{3} \cdot$ Ronald B. Sorensen ${ }^{1}$. \\ Joseph E. Knoll ${ }^{2}$. Oliva Pisani ${ }^{3}$
}

Published online: 21 May 2018

(C) The Author(s) 2018

\begin{abstract}
Interest and focus on development of renewable biofuels has been increasing over the past decade leading to the introduction of a wide cadre of renewable feedstocks. As a result, numerous perennial warm-season grasses have been introduced and management practices evaluated to determine their suitability as biofuel feedstocks. "Merkeron" napier grass (Pennisetum purpureum) plots were established in 2010 and harvested during crop years 2011 through 2015 adjacent to an on-going peanut (Arachis hypogaea L.), corn (Zea mays L.), and cotton (Gossypium hirsutum L.) cropping systems study conducted at the USDA/ARS Multi-crop Irrigation Research Farm in Shellman, GA (84 36 W, 3044 N) on a Greenville fine sandy loam (fine, kaolinitic, thermic Rhodic Kandiudults). Napier grass was produced in both non-irrigated and two irrigated levels with different levels of nitrogen and potassium fertilizers. Peanut, corn, and cotton were produced in non-irrigated and full irrigation regimes. Breakeven prices for napier grass ranged from $\$ 65$ to $\$ 84 \mathrm{Mg}^{-1}$ at variable and total costs. The breakeven napier grass price was estimated such that the net returns were equal between napier grass and peanut, cotton, corn cropping systems. At variable production cost, comparative breakeven napier grass prices for non-irrigated, 50\% irrigated, and full irrigated regimes were $\$ 77, \$ 117$, and $\$ 112 \mathrm{Mg}^{-1}$, respectively. Napier grass did not compete economically against traditional irrigated cropping systems. Depending on traditional crop prices and bioenergy feed stock prices, napier grass could offer economic opportunities in non-irrigated production environments, riparian buffer zone edges, or non-cropped marginal production areas.
\end{abstract}

Keywords Bioenergy $\cdot$ Napier grass $\cdot$ Corn $\cdot$ Cotton $\cdot$ Peanuts $\cdot$ WholeFarm $\cdot$ Breakeven price

\section{Introduction}

Interest and focus on development of renewable biofuels has been increasing over the past decade leading to the introduction of a wide cadre of renewable feedstocks. To achieve this goal, increased emphasis was placed on the development of cellulosic biofuels. Numerous annual and perennial warmseason grasses have been introduced and their management practices have been evaluated to determine their suitability as

Marshall C. Lamb

marshall.lamb@ars.usda.gov

1 USDA-ARS, National Peanut Research Laboratory, 1011 Forrester Dr., SE, Dawson, GA 39842, USA

2 USDA-ARS, Crop Genetics and Breeding Research Unit, 115 Coastal Way, Tifton, GA 31794, USA

3 USDA-ARS, Southeast Watershed Research Laboratory, 2316 Rainwater Road, Tifton, GA 31794, USA biofuel feedstocks $[1,2]$. Energy cane, high-fiber sugarcane, has been identified as a potential warm-season alternative for bioenergy production in the Southeast because of higher yield potential and similar production practices and equipment requirements for production, harvesting, and transportation used in sugarcane production [3, 4]. Essentially, all US sugarcane is produced in Florida, Louisiana, and Texas totaling 26.9 million metric tons in 2012. Economic comparison of energy cane as a bioenergy feedstock has been a focus in these regions. Five energy cane varieties were examined over varying crop length cycles in Louisiana showed variable costs ranges of $\$ 63$ to $\$ 76 \mathrm{Mg}^{-1}$ and fixed costs from $\$ 105$ to $\$ 127 \mathrm{Mg}^{-1}$ for dry matter biomass [4]. A study conducted in South Florida on mineral soil focused on the breakeven price of ethanol for ranges of biomass yields and processing costs concluding energy cane production could offer an economically feasible bioenergy feedstock [5]. Cost of production for energy cane was adopted from sugarcane budgets as agronomic practices and field operations for sugarcane and energy cane 
were similar providing a valuable platform for production costs on energy cane production in non-traditional areas $[4,5]$.

Napier grass, a $\mathrm{C} 4$ monocot with high biomass production with good drought tolerance, water use efficiency, and performance across a wide range of soil conditions, was shown to have advantages in terms of biomass production compared to Alamo switchgrass and giant miscanthus in the Coastal Plain region of Georgia [6-8]. "Merkeron" was released by the University of Georgia in 1989 with improved yield potential and disease resistance and selected for this research because of the yield potential shown across irrigated and non-irrigated production regimes [9]. Utilizing a GIS-based approach to estimate production potential of three perennial grasses (giant miscanthus (Miscanthus $\times$ giganteus), "Merkeron" napier grass (Pennisetum purpureum), and "Alamo" switchgrass (Panicum virgatum)), it was estimated that 2.2-9.4 $\mathrm{Tg}$ year $^{-1}$ of total biomass and 778-3296 Ml year ${ }^{-1}$ of ethanol could be produced annually on marginal lands (field borders and grassed waterways) in the Coastal Plain Region of Georgia.

Concerns related to reducing productive cropland for the production of biofuels are warranted and will continue into the future. However, farmer adoption of bioenergy crops will depend on the comparative economic returns and risks of bioenergy crops compared to traditional cropping systems [10]. Understanding the costs and the potential economic returns to bioenergy alternatives are prerequisite components to adoption. It is also important to understand the returns relative to traditional crops and cropping systems for varying crop prices. Producers should also consider the implications of the multi-year commitment of perennial crop production relative to the flexibility of altering annual cropping sequences as factors influencing net returns change. Cropping systems in the coastal plain of Georgia primarily consist of peanut (Arachis hypogaea L.), cotton (Gossypium hirsutum L.), and corn (Zea mays L.). In 2015, Georgia peanut acreage was 785,000 with a yield of 4330 pounds per acre and a farm gate value of $\$ 656$ million. Cotton acreage was 1.13 million yielding 966 pounds per acre with a value of $\$ 694$ million. Corn was produced on 330 thousand acres with a yield of 171 bushels per acre and a value of $\$ 194$ million. Combined the farm gate value of these crops totaled $\$ 1.5$ billion in Georgia and are the dominant row crops produced in the coastal plain region of Georgia [11]. The economic competitiveness of napier grass (Pennisetum purpureum) compared to traditional cropping systems has not been addressed. The objectives of this research are twofold: (1) address the yield response of napier grass under varying irrigation levels and fertility treatments and (2) incorporate existing data on cost of production coupled with irrigated and non-irrigated yield trial data for napier grass, peanut, corn, and cotton to address napier grass profitability relative to a peanut, corn, and cotton cropping system. Resulting from objective 2 will be cross commodity breakeven prices for each crop such that returns per acre are equal providing price points at which napier grass is economically competitive to the cropping system as well as crops with the system. The results will provide a baseline for economically comparing napier grass with existing row cropping systems in Georgia.

\section{Materials and Methods}

Field research was conducted at the USDA/ARS National Peanut Research Laboratory's Multi-crop Irrigation Research Farm in Shellman, GA, USA ( $84^{\circ} 36^{\prime} \mathrm{W}, 30^{\circ} 44^{\prime}$ $\mathrm{N}$ ) on a Greenville fine sandy loam (fine, kaolinitic, thermic Rhodic Kandiudults). "Merkeron" napier grass plots were established in 2010 and harvested during crop years 2011 through 2015 adjacent to an on-going peanut, corn, and cotton cropping systems study. Year was regarded as random with fixed treatments and the main effects and interactions tested using appropriate error terms. Data were subjected to analysis of variance (ANOVA) using SAS JMP12 and Tukey's Honest Significant Difference (HSD) was used to test in crop yield response to irrigation and fertility treatments.

\section{Napier Grass Production System}

Napier grass (cv. Merkeron) was established in $10-\mathrm{cm}$ pots in the greenhouse for transplanting the following spring. Stem cuttings ( 3 nodes lengths) were placed in a sand and soil mix during the fall of 2009. On 20 April 2010, transplants were planted in plots ( $1 \mathrm{~m}$ between plants in a row). Each plot consisted of three rows $10 \mathrm{~m}$ long ( $2 \mathrm{~m}$ between rows) with 9 plants within each row. Treatments were arranged in randomized complete block design that included four replicates under three irrigation levels. Irrigation and fertilizer treatments began in spring of 2011. Napier grass was produced in non-irrigated and irrigated environments with 3 irrigation rates $\left(0,1.1\right.$, and $\left.2 . \mathrm{cm}^{\text {irrigation week }}{ }^{-1}\right)$. The two irrigation levels were included in the study to better understand napier grass yield, quality, and economic response to irrigation rate. A $3 \times 2$ factorial design was also included for Nitrogen and Potassium fertilizer. Nitrogen rates included 84,168 , and $336 \mathrm{~kg} \mathrm{ha}^{-1}$ and potassium was applied at 45 and $90 \mathrm{~kg} \mathrm{ha}^{-1}$. Fertilizer treatments were applied in April of each year over the entire three row plot. The middle row of each plot was harvested to obtain plot yield and samples for post-harvest quality evaluation starting in 2011. Higher than normal rain events during the summer and fall of 2013 caused major lodging and resulted in a less efficient harvest. 


\section{Peanut, Corn, and Cotton Production System}

Peanut, corn, and cotton were also produced in irrigated and non-irrigated environments. A randomized block design was used to compare sprinkler irrigation with a non-irrigated control during the 2011-2015 crop years with three replications, and each crop was produced in each crop year within the rotation sequences. Conventional tillage practices were followed for peanut, corn, and cotton. Although slight variations existed in certain years due to weather or equipment availability, tillage operations basically consisted of disking, subsoiling, S-tine field cultivating, rototill to establish seed beds, and planting. Plots consisted of 18 rows established on $0.91 \mathrm{M}$ spacing with a plot length of $18 \mathrm{~m}$ long with a $3 \mathrm{~m}$ border/buffer between treatments. The middle rows were used to determine yield and obtain samples for post-harvest quality evaluations. Corn was planted at 6.5 seeds $\mathrm{m}^{-1}$. Corn varieties differed each year due to availability and consisted on P33M53RR2 (2011), P1814HR (2012), P1456HR (2013), and P1636YHR (2014 and 2015) (Pioneer Hi-Bred International, Inc., Johnston, IA). Nitrogen (28-0-0-5) was side-dressed twice for a yearly total of $235 \mathrm{~kg} \mathrm{~N} \mathrm{ha}^{-1}$ and potassium, phosphorous, and minor elements were applied based on recommended rates from soil analysis. Best management practices and in-season scouting were used for disease, weed, and insect control. A 4-row combine was used for harvest and a sample was obtained for grain moisture and test weight. Moisture was adjusted to $15.5 \%$ for final yield determination.

Cotton varieties also varied consisting of PHY375WRF (2011 and 2012) and PHY499WFR (2013, 2014, and 2015) (Dow AgroSciences, Indianapolis, IN). Cotton seeding rate was 12 seed $\mathrm{m}^{-1}$. Nitrogen was side-dressed in a single application at $82 \mathrm{~kg} \mathrm{~N} \mathrm{ha}^{-1}$ and other fertilizers were applied based on soil sample recommendations. Pesticides, growth regulators, and defoliants were applied based on field scouting and best management recommendations. Plots were harvested using a two row spindle picker using a bagging attachment to obtain samples for yield and quality determination. A $220-\mathrm{g}$ subsample was obtained and lint separated using a table top gin to obtain final lint yield. Lint was sent to the USDA cotton classing office (Macon, GA) for official grading.

The GA-06G peanut cultivar was used in all crop years at a seeding rate of $19 \mathrm{seed}^{-1}$ [12]. Best management practices were followed with respect to fertility and pest management. Harvest date was determined by the peanut maturity profile method which uses mesocarp pod color as a predictor of optimal harvest date [13]. Peanuts were dug and inverted using a 2row inverter and allowed to cure in the field to approximately $18 \%$ moisture content. Plots were $15.2 \mathrm{M}$ and harvested using a 2-row pull type peanut thresher with a bagging attachment. After harvest, samples were further cured to around $9 \%$ moisture, weighed, and riffle divided to obtain a $1800 \mathrm{~g}$ sent to the
Alabama Federal State Inspection Service (Dothan, AL) to obtain peanut grade factors including foreign material, total sound mature kernels, sound splits, other kernels, loose shelled kernels, and damage kernels. Per industry standards, final pod weight was obtained after grading by deducting foreign mature and adjusting to $7 \%$ moisture content for determining final yield.

Irrigation scheduling (timing and amount) was managed by the Irrigator Pro for peanut, corn, and cotton program developed and released by the USDA/ARS NPRL. There are separate Irrigator Pro models for peanut, cotton, and corn. The model is designed to avoid crop stress while triggering irrigation at the most efficient timing and volume to avoid overirrigation. Data required for Irrigator Pro includes soil type, planting date, daily rainfall and irrigation amounts, and growth stage. Irrigator Pro for corn and cotton uses estimated daily crop water use in accordance with established base values within various growth stages. Daily soil water potential at $0.2,0.4$, and $0.6 \mathrm{~m}$ is entered in the program. A weighted system is used to average soil water potential over the 3 depths where the shallowest sensor carries $43 \%$ of the average compared to $32 \%$ at $0.4 \mathrm{~m}$ and $25 \%$ at $0.6 \mathrm{~m}$. An average soil water potential of $-50 \mathrm{kPa}$ will trigger irrigation $[14,15]$. Irrigator Pro for peanut also includes the soil type, planting date, daily rainfall and irrigation amounts, and growth stage but in lieu of soil water potential instead uses irrigation to maintain soil temperature in the fruiting zone at recommended levels [16-18]. Irrigation in the napier grass was applied to reach a minimum of $2.54 \mathrm{~cm}$ per week in the $100 \%$ rate and 1.27 at the $50 \%$ rate.

\section{Cost of Production and Prices for Napier Grass, Peanut, Corn, and Cotton}

Data on production costs of napier grass, sugarcane, or energycane in the coastal plain region of Georgia are not available. Thus, production cost estimates were derived from two studies conducted in the Southeast USA which cost estimates for energy cane were adapted from previous research in sugarcane. Salassi et al. 2013 focused on crop establishment cost and whole farm production costs of five perennial energy cane varieties produced under differing crop cycle lengths [4]. Inclusive of annual establishment, biomass cultivation, harvest costs, and total variable cost of production was found to be approximately $\$ 1215 \mathrm{ha}^{-1}$ with fixed and overhead costs of $\$ 346$ and $\$ 74 \mathrm{ha}^{-1}$, respectively [4]. Using a similar approach and assumptions, a study in Florida concluded that the total variable costs of production for energy cane was $\$ 1836 \mathrm{ha}^{-1}$ with fixed costs of $\$ 309 \mathrm{ha}^{-1}$ [5]. Each of these used a net present value approach to estimate annualized establishment and production costs. The production costs used in this study were the average of these two studies with modifications 
specific to the implementation and management of production of napier grass in this study. For example, significant costs were associated with road and ditch maintenance and pumping and water control in sugarcane production that were not applicable to the management practices employed in this research. These costs were removed to accurately depict the actual cost. Irrigation and nitrogen and potassium fertilizers were removed from the cost estimates and replaced by actual amounts used in the study. Irrigation cost was estimated at $\$ 50.2$ per hectare-cm. Nitrogen and potassium costs were $\$ 1.10$ and $\$ 0.75$ per kilogram, respectively. In this research, all plots were planted in the same year (CY 2010) and the planting costs distributed across harvested years.

Cost of production estimates for peanut, corn, and cotton were taken from the University of Georgia Crop Extension budgets for non-irrigated and irrigated production. Variable costs for non-irrigated peanuts, corn, and cotton were $\$ 1323$, $\$ 724$, and $\$ 1006 \mathrm{ha}^{-1}$ and fixed costs were $\$ 469, \$ 237$, and $\$ 470 \mathrm{ha}^{-1}$, respectively. Irrigated variable costs were $\$ 1522$, $\$ 1477$, and $\$ 1237$ with fixed cost of $\$ 489$, \$316, and $\$ 492 \mathrm{ha}^{-1}$, respectively. Cost for irrigation was based the actual irrigation applied each year at $\$ 50.2$ per hectare-cm. Irrigated and non-irrigated land charges of $\$ 337$ and $\$ 90$ per acre to reflect regional rates were included for peanut, corn, cotton, and napier grass.

No farm level prices exist for napier grass so indirect methods to analyze economic competitiveness were employed that required the prices for the compared crops. The 5-year (2011-2015) average price in Georgia for peanuts, corn, and cotton was used in this study at $\$ 545.11 \mathrm{Mg}^{-1}, \$ 1.71 \mathrm{~kg}^{-1}$, and $\$ 223.93 \mathrm{Mg}^{-1}$, respectively [11].

\section{Breakeven Analysis}

Breakeven yields (defined as cost per acre divided by price) represent the minimum required yield to production cost at the assumed commodity price. Breakeven prices (cost per acre divided by yield) provide the prices at which production costs are covered for the given yield. The USDA-ARS WholeFarm planning system was utilized to calculate net returns and breakeven yields and prices. Breakeven yield and price provide the yield and price point at which costs of production are covered for a specific crop [19]. Cross commodity breakeven prices are also calculated within WholeFarm [16]. Cross commodity breakeven prices provide the prices change required such that the net returns between crops are equal. Calculating breakeven yields, prices, and cross commodity prices in annual crops is straightforward. However, since napier grass is a perennial with multi-year production cycle, the breakeven prices for napier grass must be also calculated relative to the peanut, cotton, corn rotation system and not just against each crop individually. Directly estimating the farm level returns of napier grass as a bioenergy feedstock is limited by the absence of price data for dry matter napier grass. However, estimates of napier grass yields and cost of production coupled with complete return analysis for peanut, corn, and cotton allow estimation of the price required for napier grass to equal profitability to other crops and the peanut, cotton, corn cropping system. For this analysis, production costs per ton and breakeven prices will be provided based on both variable and total costs of production. Focusing on variable costs only is a more direct and comparable approach when evaluating inclusion of a new crop alternative into an existing cropping system. In an existing cropping system, a portion of depreciation on existing equipment could be paid out whereas equipment required for a new crop alternative would have to be purchased and fully depreciated. A producer should not consider a crop if the price received is not sufficient to cover variable cost because out of pocket expenses are not covered (Table 1).

\section{Results and Discussion}

\section{Rainfall and Irrigation}

Total rainfall received and irrigation applied during the growing season for each crop is provided in Table 3. Total rainfall received was fairly consistent in all years for all crops with the exception of 2013. In 2013, rainfall was almost double the average received in the other growing seasons. As a result, significantly less irrigation was applied in 2013 for all crops. The rainfall received in 2013 is the primary reason the napier grass lodged and complicated harvest. However, all plots were harvested minimum yield impact. Yearly variations in rainfall between crops were attributable to planting and harvest date differences.

\section{Yields (Napier Grass, Peanut, Cotton, Corn)}

The main effect of irrigation was significant for yield for all crops: napier grass, all years $\left(30,396 \mathrm{~kg} \mathrm{ha}^{-1} 100 \%\right.$ irrigated vs. $28,114 \mathrm{~kg} \mathrm{ha}^{-1} 50 \%$ irrigated vs. $22,180 \mathrm{~kg} \mathrm{ha}^{-1}$ nonirrigated $(P<0.001))$; peanuts $\left(6395 \mathrm{~kg} \mathrm{ha}^{-1}\right.$ irrigated vs. $4205 \mathrm{~kg} \mathrm{ha}^{-1}$ non-irrigated $\left.(P<0.001)\right)$; cotton $\left(1537 \mathrm{~kg} \mathrm{ha}^{-1}\right.$ irrigated vs. $795 \mathrm{~kg} \mathrm{ha}^{-1}$ non-irrigated $\left.(P<0.001)\right)$; and corn $\left(12,847 \mathrm{~kg} \mathrm{ha}^{-1}\right.$ irrigated vs. $3228 \mathrm{~kg} \mathrm{ha}^{-1}$ non-irrigated $(P<0.001))$ (Table 2). The main effect of year was also significant $(P<0.001)$. Combined fertilizer treatment yield effects in napier grass for $\mathrm{N}$ and $\mathrm{K}$ fertilizers were not significant and are removed from the statistical model for yield to achieve greater replication (Table 2).

Differences in napier grass yield resulted between the irrigation rates and the non-irrigated yield (Table 3 ). The $100 \%$ irrigation level provided a $29 \%$ increase in yield over the nonirrigated treatment $\left(8238 \mathrm{~kg} \mathrm{ha}^{-1}\right)$ and $27 \%$ yield increase 
Table 1 Total rainfall received and irrigation applied during the 20112015 crop growing season at the USDA/ARS Shellman Multi-crop Irrigation Research Farm, Shellman, GA

\begin{tabular}{llllll}
\hline & $\begin{array}{l}2011 \\
\mathrm{~mm}\end{array}$ & 2012 & 2013 & 2014 & 2015 \\
\hline Napier grass & & & & & \\
$\quad$ Rainfall $^{\mathrm{a}}$ & 437 & 550 & 924 & 591 & 510 \\
Irrigation $^{\mathrm{b}}$ & 518 & 381 & 95 & 317 & 381 \\
$\quad$ Total water & 955 & 931 & 1019 & 908 & 891 \\
Corn & & & & & \\
Rainfall & 367 & 394 & 881 & 593 & 361 \\
Irrigation & 416 & 404 & 191 & 326 & 416 \\
$\quad$ Total water & 783 & 798 & 1072 & 919 & 777 \\
Cotton & & & & & \\
Rainfall & 325 & 330 & 787 & 348 & 335 \\
Irrigation & 376 & 320 & 132 & 292 & 320 \\
$\quad$ Total water & 701 & 650 & 919 & 640 & 655 \\
Peanut & & & & & \\
Rainfall & 325 & 330 & 790 & 348 & 335 \\
Irrigation & 355 & 356 & 113 & 298 & 298 \\
Total water & 680 & 686 & 903 & 646 & 634 \\
\hline
\end{tabular}

${ }^{a}$ Yearly variations in rainfall between crops were attributable to planting and harvest date differences

${ }^{\mathrm{b}}$ Irrigation amounts represent the $100 \%$ application level. The $50 \%$ irrigation level in the napier grass plots was applied at the same time as the $100 \%$

resulted for the $50 \%$ irrigation rate compared to the nonirrigated $\left(5957 \mathrm{~kg} \mathrm{ha}^{-1}\right)$. Although the yield difference comparing the $100 \%$ and the $50 \%$ irrigation rate was much less at $8 \%\left(2281 \mathrm{~kg} \mathrm{ha}^{-1}\right)$, significant differences resulted. Irrigated yield were comparable to reported dry biomass yields of 16.4 $\mathrm{Mg} \mathrm{ha}^{-1}$ across five energy cane varieties with yield converted to a total farm area basis in Louisiana [4]. Irrigated peanut, cotton, and corn yields were increased 52, 93, and $297 \%$ over the non-irrigated yield $(P \leq 0.05)$ during the 2011-2015 crop years (Table 2). Irrigated yield increases demonstrate the yield and economic importance of irrigation in coastal region of Georgia.
Table 3 Napier grass, peanut, cotton, and corn yield produced in irrigated and non-irrigated regimes during the 2011-2015 crop years at the USDA/ARS Shellman Multi-crop Irrigation Research Farm, Shellman, GA

\begin{tabular}{lllll}
\hline & $\begin{array}{l}\text { Napier grass } \\
\mathrm{kg} \mathrm{ha}^{-1}\end{array}$ & Peanut & Cotton & Corn \\
\hline Irrigated $(100 \%)$ & $30396 \mathrm{a}$ & $6395 \mathrm{a}$ & $1537 \mathrm{a}$ & $12847 \mathrm{a}$ \\
Irrigated $(50 \%)$ & $28114 \mathrm{~b}$ & $\cdot$ & $\cdot$ & $\cdot$ \\
Non-irrigated & $21868 \mathrm{c}$ & $4205 \mathrm{~b}$ & $795 \mathrm{~b}$ & $3228 \mathrm{~b}$ \\
\hline
\end{tabular}

Within columns for each respective crop, means followed by the same lower-case letter are not significantly different as determined by Tukey HSD pairwise comparison at $P=0.05$

The combined fertility treatments did not have an effect on napier grass yield $(P=0.054)$. Potassium rate across all $\mathrm{N}$ rates did not have a significant effect on napier grass yield $(P=0.7127)$. However, when analyzed across all $\mathrm{K}$ application rates, $\mathrm{N}$ did have a significant effect on napier grass yield $(P=0.0185)$. Napier grass yield increases were associated with higher $\mathrm{N}$ rates varied with irrigation levels (Table 4). No yield difference was associated with $\mathrm{N}$ rates in the nonirrigated regime. At the $50 \%$ irrigation level, $\mathrm{N}$ rates of 168 and $336 \mathrm{~kg} \mathrm{ha}^{-1}$ rates increased yield compared to the $84 \mathrm{~kg} \mathrm{ha}^{-1} \mathrm{~N}$ rate. No yield differences resulted at the $100 \%$ irrigation level between 84 and $168 \mathrm{~kg} \mathrm{ha}^{-1} \mathrm{~N}$ rate or comparing the 168 and $336 \mathrm{~kg} \mathrm{ha}^{-1} \mathrm{~N}$ rates. The $336 \mathrm{~kg} \mathrm{ha}^{-1} \mathrm{~N}$ rate was higher than the $84 \mathrm{~kg} \mathrm{ha}^{-1} \mathrm{~N}$ rate in the $100 \%$ irrigation level (Table 4). Higher $\mathrm{N}$ rates are important in achieving high irrigated napier grass yields but $\mathrm{K}$ rates did not influence yield.

\section{Partial Net Returns for Irrigation and N Rate}

Though yield difference between the 100 and 50\% irrigation levels was significant, added costs for applying irrigation were incurred. To address this, partial budget analysis was utilized. An assumed price for napier grass of $\$ 75 \mathrm{Mg}^{-1}$ was used to standardize revenue per hectare and the associated differences in irrigation application and rent cost were incorporated to estimate the partial net return to irrigation. Land rent cost for
Table 2 Analysis of variance for yield of napier grass, peanut, cotton, and corn for year (Y), irrigation (I), and combined fertility treatments of nitrogen and potassium ( $\mathrm{T}$ ) (napier grass only) at the USDA/ARS Shellman Multi-crop Irrigation Research Farm, Shellman, GA

\begin{tabular}{|c|c|c|c|c|c|c|c|c|}
\hline \multirow[b]{2}{*}{ Effect } & \multicolumn{2}{|c|}{ Napier grass } & \multicolumn{2}{|c|}{ Peanut } & \multicolumn{2}{|c|}{ Cotton } & \multicolumn{2}{|l|}{ Corn } \\
\hline & $F$ & $P$ value & $F$ & $P$ value & $F$ & $P$ value & $F$ & $P$ value \\
\hline $\mathrm{Y}$ & 36.94 & $<0.0001$ & 4.21 & 0.0097 & 1.20 & 0.3354 & 1.30 & 0.2954 \\
\hline I & 85.51 & $<0.0001$ & 26.27 & $<0.0001$ & 42.00 & $<0.0001$ & 92.75 & $<0.0001$ \\
\hline Y x I & 102.39 & $<0.0001$ & 37.32 & $<0.0001$ & 15.26 & $<0.0001$ & 76.27 & $<0.0001$ \\
\hline $\mathrm{T}$ & 2.08 & 0.0542 & & & & & & \\
\hline $\mathrm{Y} \times \mathrm{T}$ & 15.45 & $<0.0001$ & & & & & & \\
\hline I x T & 25.75 & $<0.0001$ & & & & & & \\
\hline$Y \times I \times T$ & 56.67 & $<0.0001$ & & & & & & \\
\hline
\end{tabular}


Table 4 Nitrogen rate effect (across potassium rates) on napier grass yield produced in irrigated and non-irrigated regimes during the 20112015 crop years at the USDA/ARS Shellman Multi-crop Irrigation Research Farm, Shellman, GA

\begin{tabular}{llll}
\hline $\begin{array}{l}N \\
\mathrm{~kg} \mathrm{ha}^{-1}\end{array}$ & Non-irrigated & IRR 50\% & IRR 100\% \\
\hline 84 & $20.604 \mathrm{a}$ & $25.807 \mathrm{~b}$ & $28.807 \mathrm{~b}$ \\
168 & $21.932 \mathrm{a}$ & $29.156 \mathrm{a}$ & $30.349 \mathrm{ab}$ \\
336 & $23.070 \mathrm{a}$ & $29.380 \mathrm{a}$ & $31.961 \mathrm{a}$ \\
\hline
\end{tabular}

Within columns for each respective crop, means followed by the same lower case letter are not significantly different as determined by Tukey HSD pairwise comparison at $P=0.05$

irrigation was applied equally in the 100 and $50 \%$ irrigation levels. Analysis of variance showed that irrigation level had a significant effect on partial net returns $(P=0.0498)$. The net return to irrigation in the $100 \%$ irrigation level did not differ from the $50 \%$ irrigation level and net returns to both irrigation levels were higher than the non-irrigated level. Thus, producer objectives would drive irrigation level. Yields are highest at the $100 \%$ irrigation level. When the added cost of irrigation between the 100 and $50 \%$ was accounted, net return in the $100 \%$ irrigation level was $\$ 23.50$ and $\$ 169 \mathrm{ha}^{-1}$ higher than the $50 \%$ and non-irrigated levels, respectively. The $50 \%$ irrigation level provided net returns $\$ 145 \mathrm{ha}^{-1}$ higher than the non-irrigated level. The partial net returns to irrigation do not imply that irrigated napier grass is more profitable per unit area or yield, but only suggest that the increased revenue from yield increases was sufficient to cover the added cost of irrigation.

Although yield increases were associated with increasing $\mathrm{N}$ rates in the irrigated regimes, partial budget analysis for $\mathrm{N}$ rates showed no difference in net returns to $\mathrm{N}$ rates $(P=$ $0.4217)$. The main reason is the significant cost of $\mathrm{N}$ at the application rates used in this study. The cost for the $\mathrm{N}$ rates of 84,168 , and $336 \mathrm{~kg} \mathrm{ha}^{-1}$ were $\$ 93, \$ 168$, and $\$ 336$ per hectare, respectively. When viewed within irrigation levels, the partial net returns to $\mathrm{N}$ did not vary within any of the irrigation rates, but the returns were numerically higher at the 168 and $336 \mathrm{~kg} \mathrm{ha}^{-1}$ than the lower rate suggesting the higher rates will provide yield stability and provide marginally higher returns to $\mathrm{N}$ application at these rates. Knoll et al. (2013) made a similar observation and suggested that soil $\mathrm{N}$ availability in a Tifton loamy sand must remain above $100 \mathrm{~kg} \mathrm{ha}^{-1}$ year $^{-1}$ in order to maintain yield stability [2].

\section{Breakeven Napier Grass Prices}

The napier grass breakeven prices $\left(\$ \mathrm{Mg}^{-1}\right)$ were obtained by dividing the cost per hectare (including land rent) by the dry matter yield. Variable cost were derived from previous studies aimed at providing energy cane production cost in Louisiana and Florida where variable cost ranged from 59 to $79 \%$ of total
Table 5 Napier grass breakeven price at variable and total production cost per ton and napier grass breakeven prices compared to the peanut, cotton, and corn cropping system in irrigated and non-irrigated regimes during the 2011-2015 crop years at the USDA/ARS Shellman Multi-crop Irrigation Research Farm, Shellman, GA

\begin{tabular}{lllll}
\hline Irrigation level & $\begin{array}{c}\mathrm{BE}-\mathrm{VC} \\
\$ \mathrm{Mg}^{-1}\end{array}$ & BE-TC & CC-napier(VC) & CC-napier(TC) \\
\hline Irrigated (100\%) & 68.89 & 88.12 & 112.11 & $\$ 116.11$ \\
Irrigated (50\%) & 69.98 & 90.77 & 116.71 & $\$ 121.03$ \\
Non-irrigated & 64.85 & 84.34 & 77.40 & $\$ 93.78$ \\
\hline
\end{tabular}

$\mathrm{BE}-\mathrm{VC}$ - napier grass breakeven price at variable production cost. BE$\mathrm{TC}$ - napier grass breakeven price at total production cost (variable cost plus fixed cost). CC-napier (VC) — cross commodity breakeven price of napier grass compared to the peanut, cotton, and corn cropping system based on variable cost (VC) of production for all crops. CC-napier (TC) - cross commodity breakeven price of napier grass compared to the peanut, cotton, and corn cropping system based on total cost (TC) of production for all crops

cost of production at the farm level $[4,5,20]$. The breakeven prices in the non-irrigated, $50 \%$ irrigated, and $100 \%$ irrigated regimes are provided in Table 5 .

Breakeven prices were lowest in the non-irrigated treatment at $\$ 64.85$ for variable cost and $\$ 84.34$ for total costs. The breakeven prices in the 100 and 50\% irrigation levels were basically the same at approximately $\$ 69$ and $\$ 90$ per ton for variable and total cost (Table 5). The increased yield in the $100 \%$ irrigation treatment and was negated by the increased irrigation application cost compared to the 50\% irrigation treatment. Though significant modifications to budgets were required due to differing production practices, costs per $\mathrm{Mg}$ were comparable to previous studies. Salassi et al. 2014 showed a range of $\$ 88$ to $\$ 101 \mathrm{Mg}^{-1}$ with land rent included over five energy cane varieties and crop cycle lengths. Mooney et al. 2009 demonstrated the importance of yield on breakeven prices for switchgrass produced on four differing soil types in Tennessee with breakeven prices ranging from $\$ 46 \mathrm{Mg}^{-1}$ (17.7 $\mathrm{Mg} \mathrm{ha}^{-1}$ yield) to $\$ 69 \mathrm{Mg}^{-1}$ (8.5 $\mathrm{Mg} \mathrm{ha}^{-1}$ yield) concluding that breakeven prices were influenced by yield, N price, and fuel prices [19].

\section{Cross Commodity Breakeven Prices}

The decision criteria for adoption of napier grass (or any crop enterprise) into existing cropping systems will depend on comparative profitability and risks. Allocation of land and resources will occur only if the returns are equal to or above the returns of existing cropping systems. A producers risk aversion and expectations of future payoffs from new crop alternatives will also impact adoption [10]. In the Coastal Plain region of Georgia, cropping systems primarily consist of peanut, cotton, and corn produced in both irrigated and non-irrigated regimes. In the absence of a reliable price series 
for napier grass or energy cane, one method to address this is the estimate the breakeven (minimum) price for napier grass at which napier grass would equal the returns over variable and total cost of the peanut, cotton, corn production system. For napier grass to compete at the $100 \%$ irrigation level, the price $\left(\$ \mathrm{Mg}^{-1}\right.$ ) would have to be $\$ 112.11$ for variable cost and $\$ 116.11$ for total cost (Table 5). At the 50\% irrigation level, the napier grass price would be $\$ 116.71$ and $\$ 121.03$ for variable and total cost, respectively. The non-irrigated napier grass competitive price was lower than each of the irrigated rates at $\$ 77.40$ and $\$ 93.78 \mathrm{Mg}^{-1}$ (Table 5).

An alternative method to address this is to estimate the price change for peanuts, cotton, and corn that would be required for equal returns of the peanut, cotton, corn production system to napier grass. This method provides more intuitive price comparisons for these traditional crops because the markets are established and prices are consistently reported. We assume that the crop mix is equally balanced with peanut, cotton, and corn for comparison with napier grass. The breakeven prices are calculated for total costs (variable and fixed costs) for all crops. If the cross commodity breakeven price for peanuts (for example) is below the price received for peanuts, then napier grass (the comparison crop) provides higher net returns than peanuts. If the price received for peanuts is greater than the breakeven then peanuts are more profitable. In the non-irrigated regime, the minimum prices for peanuts, cotton, and corn would be $\$ 415.50 \mathrm{Mg}^{-1}, \$ 1.61 \mathrm{~kg}^{-1}$, and $\$ 336.14 \mathrm{Mg}^{-1}$. In the 50\% irrigation level, the prices for peanuts, cotton, and corn would be $\$ 390.53 \mathrm{Mg}^{-1}, \$ 1.41 \mathrm{~kg}^{-1}$, and $\$ 191.56 \mathrm{Mg}^{-1}$, respectively. In the $100 \%$ irrigation level, the prices for peanuts, cotton, and corn would be $\$ 394.29 \mathrm{Mg}^{-1}, \$ 1.42 \mathrm{~kg}^{-1}$, and $\$ 193.56 \mathrm{Mg}^{-1}$, respectively.
To address this further, recent historical prices for peanut, cotton, and corn were used to determine the number of years in which napier grass would economically compete against each crop within the peanut, cotton, corn cropping system. The five (2011-2015) and ten (2006-2015) year average prices were: peanuts $\left(\$ 545.71\right.$ and $\left.\$ 498.32 \mathrm{Mg}^{-1}\right)$, cotton $\left(\$ 1.70 \mathrm{~kg}^{-1}\right.$ and $\left.\$ 1.55 \mathrm{~kg}^{-1}\right)$, and corn $\left(\$ 223.93 \mathrm{Mg}^{-1}\right.$ and $\left.\$ 198.73 \mathrm{Mg}^{-1}\right)$ [11].

The required breakeven prices in the 50 and $100 \%$ napier grass irrigation levels were basically the same. The main reason is that the production cost per ton and the partial net returns to irrigation between the two irrigation rates were very close because the additional per hectare revenue in the $100 \%$ irrigated napier grass was basically negated by the additional irrigation application cost compared to the 50\% irrigated napier grass. Within 50 and $100 \%$ irrigation treatments, the required breakeven for peanuts was not reached in either the 5 or 10 -year periods showing that irrigated peanuts were more profitable. In cotton the required breakeven price was not reached during the 5-year period and was reached only two times during the 10 -year price period. For corn, the breakeven price was reached in 2 years during the 5-year period and 7 years of the 10 -year period. The results indicate that under recent crop prices and production levels, napier grass will not compete against traditional irrigated cropping systems.

In non-irrigated production regime napier grass was, however, more competitive. Table 6 provides the yearly nonirrigated napier grass yield, breakeven napier grass price relative to the peanut, cotton, corn cropping system, and the breakeven price of each crop within the cropping system compared to napier grass. For non-irrigated practices, the required breakeven price for peanuts was not reached during the 5-year
Table 6 Yearly non-irrigated napier grass yield, total production cost per ton, and breakeven prices for peanut, cotton, and corn are equal returns result for napier grass and each crop for the 2011-2015 crop years at the USDA/ARS Shellman Multi-crop Irrigation Research Farm, Shellman, GA

\begin{tabular}{lllllll}
\hline \multicolumn{5}{c}{ Breakeven prices } \\
\cline { 5 - 7 } Year & $\begin{array}{l}\text { Yield } \\
\mathrm{kg} \mathrm{ha}^{-1}\end{array}$ & $\begin{array}{l}\text { Napier grass }^{\mathrm{a}} \\
\$ \mathrm{Mg}^{-1}\end{array}$ & $\begin{array}{l}\text { Napier grass } \\
\$ \mathrm{Mg}^{-1}\end{array}$ & $\begin{array}{l}\text { Peanuts } \\
\$ \mathrm{Mg}^{-1}\end{array}$ & $\begin{array}{l}\text { Cotton } \\
\$ \mathrm{~kg}^{-1}\end{array}$ & $\begin{array}{l}\text { Corn } \\
\$ \mathrm{Mg}^{-1}\end{array}$ \\
\hline 2011 & $21,448 \mathrm{~b}$ & 83.11 & 92.01 & 405.70 & 1.65 & 321.96 \\
2012 & $26,156 \mathrm{a}$ & 68.63 & 75.44 & 508.19 & 2.12 & 466.42 \\
2013 & $26,451 \mathrm{a}$ & 67.36 & 74.59 & 514.67 & 2.16 & 475.86 \\
2014 & $19,698 \mathrm{~b}$ & 91.14 & 100.18 & 367.62 & 1.48 & 268.44 \\
2015 & $15,580 \mathrm{c}$ & 112.93 & 126.66 & 278.00 & 1.06 & 142.09 \\
Average & 21,868 & 84.63 & 93.78 & 414.83 & 1.69 & 334.95 \\
\hline
\end{tabular}

Within the column for napier grass yield, means followed by the same lower-case letter are not significantly different as determined by Tukey HSD pairwise comparison at $P=0.05$

${ }^{\text {a }}$ Yearly napier grass breakeven price at total production cost

${ }^{\mathrm{b}}$ The breakeven napier grass price represents the price point at which the returns per hectare are equal between non-irrigated napier grass and the peanut, cotton, corn cropping system. Napier grass price above (below) the breakeven would imply positive (negative) returns to napier grass compared to the cropping system

${ }^{\mathrm{c}}$ The breakeven prices for each crop represent the price point at which the returns per hectare are equal between the non-irrigated crop and napier grass. Crop prices above (below) the breakeven price for individual crop would imply that the returns for the crop are greater than (less than) the returns to napier grass 
period and twice during the 10-year period (Table 6). For cotton, the required breakeven price occurred during 2 years $(40 \%)$ and 5 years $(50 \%)$ for the respective time periods. For non-irrigated corn, the required breakeven price was reached every year over both time periods (Table 6). Because of the reduced non-irrigated corn yield in Georgia (38\% of nonstress yields), limited acres are devoted to corn in nonirrigated production. Since napier grass is more competitive in a non-irrigated regime, it is most likely that producers will consider this option especially in periods of reduced crop prices or higher prices for bioenergy feedstocks.

The results of the relative profitability of traditional cropping systems in irrigated and non-irrigated production environments parallel a Southeastern cropping system study focused on net returns of individual crops in irrigated and nonirrigated cropping system. Net returns were most influenced by irrigation, crop rotation sequence, and commodity price. Peanuts contributed the highest influence to net returns followed by cotton and lastly corn within the cropping system [21]. These breakeven prices reflect the competiveness of napier grass grown as a perennial crop compared to individual annual crops commonly grown in rotation sequences together. Producers would have to consider their specific crop rotation sequences, productivity, and future price expectations. The results provide the breakeven price points relative to recent historical prices required for consideration of napier grass compared to traditional rotations.

\section{Conclusions}

This study provides results from a 5-year study on the yield and variable cost of production (including land rent) per ton for napier grass produced in non-irrigated and irrigated regimes on the Coastal Plain region in South Georgia. On a dry matter basis, breakeven napier grass prices at variable cost ranged from $\$ 65$ to $\$ 69 \mathrm{Mg}^{-1}$ depending on irrigation regime and fertility treatments and breakeven prices at total cost ranged from $\$ 84$ to $\$ 91 \mathrm{Mg}^{-1}$. These estimates provide information the initial criteria for consideration of napier grass as a potential crop in coastal plain region of Georgia. In addition, economic comparisons were made with a traditional cropping system in the region consisting of peanut, cotton, and corn to calculate the price required for economic competitiveness. The price required for napier grass to compete with the peanut, cotton, corn production system ranged from $\$ 99$ to $\$ 121 \mathrm{Mg}^{-1}$ with total costs included mainly dependent on irrigation rate. Since no prices are established for napier grass, the breakeven prices for peanut, cotton, and corn were calculated individual and as a cropping system to address napier grass competitiveness. Napier grass was found to be more economically competitive with the peanut, cotton, corn cropping system in non-irrigated production than in irrigated production. Risks must also be considered as crop insurance coverage is available minimize downside yield and price risks for peanuts, cotton, and corn. At recent prices and yields for napier grass, peanut, cotton, and corn observed in this 5-year study, napier grass will not compete economically against traditional irrigated cropping systems. However, depending on prices for traditional crops and bioenergy feedstocks, napier grass could offer economic opportunities in non-irrigated production systems (depending on crop mix), riparian buffer zones, and non-cropped areas. Napier grass showed positive yield responses to irrigation and nitrogen. However, net returns associated with higher irrigation and nitrogen levels were basically the same because of the added costs. Future research improving water use efficiency, drought tolerance, or $\mathrm{N}$ efficiency of napier grass would increase the economic competitiveness of napier grass. Economic analysis of napier grass production in riparian buffer zones and noncropped areas will be addressed in the future. The results of this research provide the baseline for Southeast producers to evaluate napier grass production in both irrigated and non-irrigated environments relative to traditional cropping systems.

Open Access This article is distributed under the terms of the Creative Commons Attribution 4.0 International License (http:// creativecommons.org/licenses/by/4.0/), which permits unrestricted use, distribution, and reproduction in any medium, provided you give appropriate credit to the original author(s) and the source, provide a link to the Creative Commons license, and indicate if changes were made.

\section{References}

1. Knoll JE, Anderson WF, Strickland TC, Hubbard RK, Malik R (2012) Low-input production of biomass from perennial grasses in the coastal plain of Georgia, USA. BioEnergy Res 5:206-214

2. Knoll JE, Anderson WF, Malik R, Hubbard RK, Strickland TC (2013) Production of Napier grass for bioenergy under organic versus inorganic fertilization in the Southeast USA. BioEnergy Res 6(2):1-10

3. Mark TB, Salassi ME, Deliberto MA (2009) Developing a cellulosic ethanol industry in Louisiana. La Agicu 53(4):10-11

4. Salassi ME, Brown K, Hilbun BM, Deliberto MA, Gravois KA, Mark TB, Falconer LL (2014) Farm-scale cost of producing perennial energy cane as a biofuel feedstock. Bioenerg Res 7:609-619

5. Alvarez, J. and Z.R. Helsel. 2011. Economic feasibility of biofuel crops in Florida: energycane on mineral soils. Univ. of Florida, IFAS Extension. EDIS document SC089

6. Anderson WF, Dien BS, Brandon SK, Peterson JD (2008) Assessment of bermudagrass and bunch grasses as feedstocks for conversion to ethanol. Appl Biochem Biotechnol 145:13-21

7. Coffin AW, Strickland TC, Anderson WF, Lamb MC, Lowrance RR, Smith CM (2016) Potential for production of perennial biofuel feedstocks in conservation buffers on the coastal plain of Georgia, USA. Bioenerg. Res. 9:587-600

8. Hanna WW, Chaparro CJ, Mathews BW, Burns JC, Sollenberger LE, Carpenter JR (2004) Perennial Pennisetums. 2004. In warmseason $\left(\mathrm{C}_{4}\right)$ grasses. Edited by LE Moser, BL Burson, and LE Sollenberger. Agronomy 45:503-520

9. Burton GW (1989) Registration of "Merkeron" napiergrass. Crop Sci 29:1327 
10. Skevas T, Swinton SM, Tanner S, Sanford G, Thelen KD (2016) Investment Bioenergy Crops. GCB Bioenergy 8:1162-1177. https://doi.org/10.1111/gcbb.12320

11. USDA-NASS. 2016. Quick stats data base. Available at http:// www.nass.usda.gov (accessed 10 October 2016). USDA Natl. Agric. Statistics Serv., Washington, DC

12. Branch WD (2007) Registration of 'Georgia-06G' peanut. J Plant Reg 1:120-120

13. Williams EJ, Drexler JS (1981) A non-destructive method for determining peanut pod maturity. Peanut Sci. 8:134-141

14. Lamb M, Sorensen R, Nuti RC, Butts CL, Faircloth WH, Eigenberg D, Rowland DL (2011) Agronomic and economic effect of irrigation rate in corn produced in Georgia. Online Crop Management 10. https://doi.org/10.1094/CM-2011-0721-02-RS

15. Lamb, M., Sorensen, R., Nuti, R. C., Butts, C.L. 2014. Agronomic and economic effect of irrigation rate in cotton. Online. Crop, Forage, and Turfgrass Management. https://doi.org/10.2134/ ctfm2014.0061
16. Davidson, J.I., Jr, M.C. Lamb, C.L. Butts, E.J. Williams, and M. Singletary. 2005. Applications of expert systems in peanut production. In H.E. Pattee and H.T. Stalker, (eds.). Advances in peanut science. Amer. Peanut Res. Educ. Soc. Inc., Stillwater

17. Lamb MC, Sorensen RB, Nuti RV, Rowland DL, Faircloth WH, Butts CL, Dorner JW (2010) Impact of sprinkler irrigation amount on peanut quality parameters. Peanut Sci 37:100-105

18. Nuti RC, Lamb MC, Sorensen RB, Truman CC (2009) Agronomic and economic response to furrow diking in irrigated and nonirrigated cotton (Gossypium hirsutum L.). Agric Water Manag 96: 1078-1084

19. Mooney DF, Roberts RK, English BC, Tyler DD, Larson JA (2009) Yield and breakeven price of 'Alamo' switchgrass for biofuels in Tennessee. Agron J 101(5):1234-1242

20. Balat M, Balat H (2009) Recent trends in global production and utilization of bio-ethanol fuel. Appl Energy 86:2273-2282

21. Lamb MC, Rowland DL, Sorensen RB, Butts CL, Faircloth WH, Nuti RC (2006) Economic returns of irrigated and non-irrigated peanut based cropping systems. Peanut Sci 33:85-92 